\title{
Breaking the Stage: From Te Matatini to Footprints/Tapuwae
}

TE RITA PAPESCH, SHARON MAZER

\begin{abstract}
The post-imperial writers of the Third World therefore bear their past within them - as scars of humiliating wounds, as instigation for different practices, as potentially revised visions of the past tending towards a post-colonial future, as urgently reinterpretable and redeployable experiences, in which the formerly silent native speaks and acts on territory reclaimed as part of a general movement of resistance, from the colonist. ${ }^{1}$
\end{abstract}

You can take my marae to the stage but don't bring the stage to my marae. ${ }^{2}$

\section{Mihi}

Kei te mingenga e pae nei, tēnā koutou, tēnā koutou, tēnā tātou katoa. Ahakoa i tukuna ngā mihi i nākuanei kua riro māku anō te mihi nā māua ki a koutou i tēneki wā, nā reira, nau mai, haere mai ki 'Ka Haka - Empowering Performance'. Ko te tūmanako ka areare ngō koutou taringa ki ngā māua kōrero. Ki te kore waiho ngā kōrero ki ngā pā tū o te whare neki ki reira

Edward Said, Culture and Imperialism (1993. London: Vintage, 1994) 256. John Te Ruruhe Rangihau, personal communication with Te Rita Papesch, 2007. 
iri atu ai hei kohinga kōrero mā ngā uri whakaheke. Kāti. Ka huri ki a Sharon māna tā māua kauwhau e whakatūwhera. ${ }^{3}$

\section{Kaupapa}

There's too much talk of decolonising the stage, as if the theatre were not itself a colonial artefact, a hangover from the settlers' desire to appear civilised in what they saw as a savage land. Here we reject the notion of 'syncretic' or 'hybridic' theatre, because when European and Māori performance practices meet and mingle under the proscenium arch waters that should be troubled are smoothed beyond recognition. We want to see the stage broken open, its fragments exposed to a critical gaze that recalls rather than transcends social history, that seeks not to console but to confront and catapult us, if not into direct action, then into a conversation that does more than keep us contained within the frame of the dominant culture. This paper is written as two sides of an ongoing debate about the relationship between the theatrical and the social in not-quite-post colonial Aotearoa New Zealand. We look at Te Matatini - the biannual national Kapa Haka Festival, most recently held in Christchurch in March 2015 - and at Footprints/Tapuwae - a bicultural opera first produced in 2001 and revived in June 2015 by the Free Theatre Christchurch - to find powerful cultural performances and contrary theatricalities in $21 \mathrm{st}$ century Aotearoa New Zealand.

3 Welcome to all who are gathered here today. Although you have been previously welcomed onto the marae I have been given the task of welcoming you again at this time on behalf of myself and Dr. Mazer, so welcome to 'Ka Haka - Empowering Performance'. Hopefully you will find something to listen to in our presentation. If not at least we will be adding to the history and stories of this house as information for those who follow. And now Sharon will begin our talk. (All translations in this document are by Te Rita Papesch unless otherwise stated.)

Te Kaharoa, Special Edition, Ka Haka - Empowering Performance: Mãori and Indigenous Performance Studies Symposium, vol. 9, 2016, 


\section{The colonising stage}

[Sharon]

In Decolonizing the Stage: Theatrical Syncretism and PostColonial Drama, Christopher Balme takes up the term 'syncretism' from its origins in comparative religion, where it is used to describe the process whereby one religion - typically Christian - absorbs another - almost certainly indigenous. He argues, rather optimistically and perversely I think, that while religious syncretism can be seen to be instrumental in acts of colonisation, theatrical syncretism

is one of the most effective means of decolonizing the stage, because it utilizes the performance forms of both European and indigenous cultures in a creative recombination of their respective elements, without slavish adherence to one tradition or the other. (3)

How can this be true, I wonder? How is it possible that the tool of the coloniser can so readily, and somehow effectively, be turned against the system from which it arises?

Balme claims that syncretic theatre in Aotearoa New Zealand, as elsewhere in the world, can be 'decolonizing', because there's a bit of this Pākehā stuff and a bit of that Māori. Think of it as a kind of theatrical pic-n-mix that, when the one is stirred into the other, appears reciprocal and egalitarian. In making his case, he looks to Edward Said's Culture and Imperialism (1993) for inspiration. Said was, himself, looking to Decolonizing the Mind by Ngũgĩ wa Thiong'o (1986), in particular for his discussion of Aimé Césaire's revisioning of The Tempest (Une Tempête) as 'an affectionate contention with Shakespeare for the right to represent the Caribbean'. ${ }^{4}$ For Said, and for Balme in his turn, the repudiation of empire by theatrical

Said 256-257. More radical in his thinking, perhaps, than Said and Balme, Ngũgi wrote Decolonizing the Mind as an argument for turning away from English in order to embrace his native language more directly.

Te Kaharoa, Special Edition, Ka Haka - Empowering Performance: Māori and Indigenous Performance Studies Symposium, vol. 9, 2016, 
means is, at least potentially, to be achieved by first calling into consciousness the 'community's history whole, coherently, integrally' (259), then moving beyond resistance as 'a reaction to imperialism' to find 'an alternative way of conceiving human history' (260), before finally pulling 'away from separatist nationalism toward a more integrative view of human community and human liberation' (261). He argues for hybridity as the contemporary human condition: 'No one today is purely one thing' (407, italics in original). In discussing the construction of cultures and cultural identities he is surely right, but what of the theatre - itself a legacy of colonisation, its architecture still European, framing and containing the stories, peoples and actions represented therein?

It is true that we can see something like syncretism in plays such as Nga Tangata Toa and Waiora, both written by Hone Kouka in the early 1990s. ${ }^{5}$ These exemplary plays, and others like them, were radical in their time for the way they introjected Māori ritual and performance practices into the dramatic action, weaving karakia and karanga, haka and waiata around dialogic scenes that were modelled on Ibsenian drama and built on the tenets of psychological realism. Nga Tangata Toa is a revisioning of Henrik Ibsen's The Vikings at Helgeland (1857), ${ }^{6}$ set at the end of the first world war. It begins with a karanga and a haka pōwhiri, staged in an almost realist mode as the welcome to returning soldiers. The ending also features a karanga, but this one comes from outside the realist frame,

5 Nga Tangata Toa was first produced by Taki Rua Theatre in 1994. Waiora: Te Ükaipō - The Homeland was first produced by Downstage Theatre in 1996. See: William Peterson, 'Reclaiming the Past, Building a Future: Maori Identity in the plays of Hone Kouka', Theatre Research International (2001) 15-24. Also: Sharon Mazer, 'Here as Elsewhere: Thinking Theatrically / Acting Locally', Antipodes 28.1 (2014) 35-45. For further context and a brief overview of the development of Māori playwriting, see Diana Looser, Remaking Pacific Pasts: History, Memory, and Identity in Contemporary Theatre from Oceania (Honolulu: University of Hawai i Press, 2014.

6 Ibsen's play, it must be noted, itself follows the example set by Richard Wagner in his Ring cycle.

Te Kaharoa, Special Edition, Ka Haka - Empowering Performance: Mãori and Indigenous Performance Studies Symposium, vol. 9, 2016, 
from the tupuna who call Rongomai into the sea: 'The lights fade on her as she walks. There is rain, the tears of Rangi'. ${ }^{7}$

Following the model set by Ibsen in his early play, which is more epic than realist, Nga Tangata Toa is written in what might be termed formal language, and as a result, the intermingling of ritual and dramatic action creates a heightened sensibility that verges on the operatic. In contrast, Waiora is a more intimate play, set in 1965 and arising out of the playwright's familial memories. Scenes modelled on Ibsenian psychological realism, in which what characters say to each other is underscored and driven by unspoken secrets and desires, alternate and ultimately are fused with mystical sequences in which the spirits hover and call. It begins with the tipuna, four figures who 'appear in the waking light' and sing 'Taukuri E' while 'preparing the place for the events of the day'. ${ }^{8}$ As spirits of the ancestors, the tipuna create a force field that envelops the living human characters, largely without their knowing. In the end, as they pull at Rongo - the young, disaffected daughter calling her into the sea, they are both honoured and defeated by the actions of her father and brother, whose haka recalls her to land and life. The play closes with a karakia that ushers the tīpuna out, and the whānau's cry of 'Tihei Mauri Ora!' (109).

Both Nga Tanagata Toa and Waiora are, at centre, plays about whānau coming to terms with the effects of past actions on the present moment, and about how such conflicts are complicated by the affective presence of Pākehā. What makes these plays powerful, however, is the tension between the two modes of performance, the Māori and the Pākehā, where in the end, a Māori way of performing - and by extension, being appears to supersede that of Pākehā to reclaim both the stage and the society it represents. In this, Kouka's plays might be seen to confirm Balme's vision of syncretic theatre.

$7 \quad$ Hone Kouka, Nga Tangata Toa (Wellington: Victoria University Press, 1994) 63 , italics in original.

8 Hone Kouka, Waiora: Te Ūkaipō - The Homeland (Wellington: Huia Publishers, 1997) 15, italics in original.

Te Kaharoa, Special Edition, Ka Haka - Empowering Performance: Māori and Indigenous Performance Studies Symposium, vol. 9, 2016, 
But can such plays thus also be seen to decolonise the stage, in the way that Balme and those who follow his reasoning idealise? I think not. For me, the theatrical - whether artfully transformed into something that meets the idea(l) of marae halfway, as for Nga Tangata Toa in its premiere production, ${ }^{9}$ or in a proscenium frame as for Waiora-predominates regardless. It overlooks the drama, beneficent perhaps, in being open to the drama within, but no less powerful for holding these Māori plays in its frame. It, like the act of colonisation and the not-quitepost-colonial society that it represents, must be seen for what it is in order to be challenged and, perhaps, transformed.

[Te Rita]

I am still coming to terms with what is actually meant by 'syncretic theatre' when it is applied to a Kapa Haka performance on a stage under a proscenium arch so I don't quite agree with Sharon. I, too, turn to Balme's book Decolonizing the Stage to understand what syncretic theatre is. He states:

\begin{abstract}
'decolonization' of the stage can be examined through a number of formal strategies which involve the combination and amalgamation of indigenous forms within the framework of the western notion of theatre. (304)
\end{abstract}

I believe that Kapa Haka goes through a process of amalgamation and combination, that is theatrical syncretism, via composition and performance to decolonise the stage.

9 As William Peterson describes it, 'designer Dorita Hannah's set for Nga Tangata Toa quoted the features of the marae and offered spectator/ participants the opportunity to plant their feet firmly in the "black sand" which is characteristic of the East Coast of the North Island where the events of the play took place' (18).

Te Kaharoa, Special Edition, Ka Haka - Empowering Performance: Māori and Indigenous Performance Studies Symposium, vol. 9, 2016, 
Composers of Kapa Haka items, especially whakaeke (entrance), whakawātea (exit), waiata-ā-ringa (action song) and poi, often use Pākehā tunes currently popular on the radio, on video and films. These composers are also amalgamating dance movements and instruments of other indigenous peoples, as I have previously stated:

For example for their whakaeke at Te Matatini 2013 the kapa haka, Te Kotahitanga, chose a tune very much like a First Nations Peoples' chanted song and they accompanied it with a 'tomtom' drum. Even the lyrics were very minimal and repetitive, which is how a chanted song of the First Nations Peoples would sound to an ear that did not understand their language. Modern Māori people are not so cut off from this wider world as Kapa Haka provides a way of seeing beyond local and becoming global from a Māori perspective. ${ }^{10}$

These amalgamated items, when combined with te reo Māori and items of ritual, such as haka (posture dance or dance of war), waiata koroua (traditional chant songs) and sometimes karanga (calling), create what I understand to be syncretic theatre.

Kapa Haka on the Festival stage provides a 'place' and 'space' for songs and haka about the political issues affecting iwi Māori to be performed. The structures and components of Kapa Haka allow us to remain true to the past while debating how to act in the present toward a future we are creating together. The Kapa Haka stage gives us a place to stand and keeps a link to the past so we can move forward. It allows iwi to remain in conversation together. It moves us from the

10 Te Rita Papesch, Creating a Modern Māori Identity through Kapa Haka (PhD. Thesis, Theatre and Film Studies: University of Canterbury, 2015) 31. A more extensive discussion of the history of Kapa Haka, including relevant sources, as outlined in this paper can be found in this thesis.

Te Kaharoa, Special Edition, Ka Haka - Empowering Performance: Māori and Indigenous Performance Studies Symposium, vol. 9, 2016, 
personal to meet the political. In so doing Māori are empowered by our performances on the theatrical stage, where our compositions of resistance and hope encourage Māori to become involved in pressing issues of the present looking towards a better future. Linda Smith has this to say in her book Decolonizing Methodologies: "The past, our stories local and global, the present, our communities, cultures, languages and social practices - all may be spaces of marginalization, but they have also become spaces of resistance and hope". ${ }^{11}$

Although I was introduced to Kapa Haka performances at an early age, my pathway to embodying that kind of performance was not a usual one and not achieved until well into my teenage years. At the tender age of ten, my parents sent me to have my voice trained in classical singing, and I also learnt how to play the piano to a standard where I was able to accompany myself when I sang opera, lieder, oratorio and so on. On arrival at secondary school I met Maria Bradshaw from Tūhourangi/Ngāti Wāhiao of Rotorua and Ngāi Tahu. She taught me Māori songs and dances and encouraged me to get involved with Kapa Haka. I discovered that I could use my opera training in the Kapa Haka performance in terms of vocal techniques and musical composition based in the Western octave scale. I still use those skills today in the tutoring of and composing for Kapa Haka. So if we are talking about empowering performance my own performance was empowered not only by a desire to learn how to be more Māori, on stage and off, but also by being able to use a knowledge of techniques that I did not gain from performing in a Māori space.

11 Linda Tuhiwai Smith, Decolonizing Methodologies: Research and Indigenous Peoples (Dunedin: University of Otago Press, 1999) 4.

Te Kaharoa, Special Edition, Ka Haka - Empowering Performance: Māori and Indigenous Performance Studies Symposium, vol. 9, 2016, 


\section{Te Matatini}

[Te Rita]

There are a number of historical accounts of the genesis of group and individual haka performances such as Te Patunga a Kae, Kahureremoa and Ponga and Puhihuia but the origin of Kapa Haka as we know it today is often traced to Makareti Papakura (Maggie) in the late nineteenth century. She was instrumental in putting together concert parties to entertain tourists visiting the wondrous geyser lands and hot pools in Rotorua, and she went on to take her troupes to Australia and England.

Fast forward to 1972: the creation of a National Kapa Haka Festival served multiple purposes. In the first instance, the Festival was to provide an avenue for the retention and revitalisation of te reo through the composition of new songs alongside the old. It was also explicitly designed to professionalise performers working in the tourist industry. Kiore Enterprises Ltd. prepared a report for Te Puni Kokiri on The Place and Role of Kapa Haka in Modern New Zealand Society. A Report To Inform Te Matatini. It describes how the first Festival came to be and discusses the changes made to the name of the Festival in the years that followed:

The first festival of Māori performing arts was held in Rotorua in 1972, funded by the Māori Purposes Fund Board. Responsible for promoting health, education, social and economic welfare of Māori, the Māori Purposes Fund Board (constituted under the Māori Purposes Fund Act 1934-35) encouraged the teaching of Māori arts and crafts and the preservation of the Māori language. ${ }^{12}$

12 Kiore Enterprises Ltd. An unpublished report for Te Puni Kokiri on The Place and Role of Kapa Haka in Modern New Zealand Society. A Report To Inform Te Matatini. (2)

Te Kaharoa, Special Edition, Ka Haka - Empowering Performance: Māori and Indigenous Performance Studies Symposium, vol. 9, 2016, 
A further reflection on the Festival's original goals can be found in the 1996 Festival programme: These objectives were discussed in 1964 with the idea of constituting a committee to consider that the Board "sponsor and grant prizes for a National Māori Cultural Competition". 13 The Kiore Enterprises Report goes on:

\begin{abstract}
The establishment of a cultural festival was supported at the 1969 National Development Conference. In 1970 the Minister of Māori Affairs established a committee to oversee and convene what were to become known as Polynesian Festivals (at both regional and national levels). ${ }^{14}$
\end{abstract}

Richards and Ryan note that the recommendations put forward at the conference were: "to an extent a confirmation of an existing framework of competition that already existed on a smaller scale at regional level". 15 Richards and Ryan add that their view was that the introduction of this new competition or Festival was probably less a desire to enhance and support Māori and Polynesian cultural aspirations as an opportunity to: "better Māori performance in the commercial arena of tourist productions". ${ }^{16}$ It was generally felt among those who wanted to promote te reo and tikanga that the performances for tourists were lacking in this area and that there needed to be checks and balances to monitor tourist performance. According to the Kiore Enterprises Report:

\footnotetext{
13 Aotearoa Traditional Māori performing Arts Society (ATMPAS), Festival Rotorua, programme (1996), unpaged.

14 Kiore Enterprises Ltd. An unpublished report for Te Puni Kokiri on The Place and Role of Kapa Haka in Modern New Zealand Society. A Report To Inform Te Matatini. 3.

15 Parehau Richards and Christopher Ryan, The Aotearoa Traditional Māori Performing Arts Festival 1972 - 2000. A case study of cultural event maturation' in The Journal of Tourism and Cultural Change 2.2. (2004) 99.

16 Ibid. 100.
}

Te Kaharoa, Special Edition, Ka Haka - Empowering Performance: Māori and Indigenous Performance Studies Symposium, vol. 9, 2016, 
The involvement of the Tourist Development Council Sub-Committee on Polynesian Entertainment reinforced this position, as did Kāretu in his book 'Haka -The Dance of a Noble People', who wrote that the festival objectives were to: "raise the standard of performance for, primarily, tourist consumption and to provide an incentive for the tribes to actively revive the traditional chant and haka of their own areas". ${ }^{17}$

The initial focus of the Festival was, and still is, traditional Māori performing arts. Today the term Kapa Haka is used to convey the story of traditional Māori performing arts. I would like to propose that this tradition can be seen to be an invented tradition, as articulated by Rustom Bharucha in Theatre and the World. Bharucha says:

Tradition can be invented in any number of ways, even though we may not be aware of it. ... More often than not, when people 'invent' tradition ('authentic' or 'spurious' through acts of cultural 'preservation' or 'subversion') they unavoidably imply that they are no longer in touch with its immediacies. Yet an illusion is often maintained whereby the 'invention' is placed within the mainstream of tradition itself. 18

Most items in a Kapa Haka performance come from a traditional, cultural practice space, that is the marae. Those items include waiata koroua (traditional song), haka pōwhiri (welcome dance), various haka (posture dance) styles such as

17 Kiore Enterprises Ltd. An unpublished report for Te Puni Kokiri on The Place and Role of Kapa Haka in Modern New Zealand Society. A Report To Inform Te Matatini. 80.

18 Quoted in Te Rita Papesch, Creating a Modern Mãori Identity through Kapa Haka (PhD. Thesis, Theatre and Film Studies: University of Canterbury, 2015) 318.

Te Kaharoa, Special Edition, Ka Haka - Empowering Performance: Māori and Indigenous Performance Studies Symposium, vol. 9, 2016, 
manawera, ngeri and pōkeka, karanga (calling) and whaikōrero (speechmaking) and poi (ball on the end of a string). When the Festival first began whakaeke (entering as if on to a marae) could be included in the above list. Today whakaeke and whakawātea (clearing the stage) have moved way beyond the traditional with the inclusion of weaponry, various props, bits and pieces of chants, haka and popular song tunes. If we include whakaeke of today, whakawātea, and waiata-ā-ringa (action song) into the gathering of the items mentioned previously we have what I now call in 'invented' tradition.

We Māori, in our Kapa Haka performances, have empowered ourselves to open up the 'traditional' to now include the 'contemporary' to produce what is now an 'invented' tradition. It has become a tradition, albeit 'invented', because we have been performing items such as waiata-ā-ringa for over a hundred years. I also believe that it has been through this 'invented' tradition that we have been able to decolonise the stage and 'break it open' to work as a performance space for Kapa Haka.

\section{[Sharon]}

For me, sitting on the sidelines at Te Matatini, Kapa Haka performs the story of colonisation and its repudiation. ${ }^{19}$ Watching whakaeke, in which kapa are directed to enter the stage 'as if' onto a marae, invokes the ritual of pōwhiri and its conversion into theatrical display. The 'as if' echoes Stanislavski's instruction to actors to perform an imaginative identification with their characters in psychological realism. Regardless of the Festival framers' intentions, this directive thus reflects a theatre-centric understanding well in advance of the

19 Here I am repeating an argument that I have rehearsed before. See: 'Performing Māori: Kapa Haka on the Stage and on the Ground', Popular Entertainment Studies 2.1 (2011) 41-5; and 'You Talkin' to Me? Eavesdropping on the Conversation at Te Matatini Māori Performing Arts Festival', Performance Research 16.2 (2011) 44-49.

Te Kaharoa, Special Edition, Ka Haka - Empowering Performance: Māori and Indigenous Performance Studies Symposium, vol. 9, 2016, 
action. Entering the stage as they would onto a marae would seem to position the kapa as manuwhiri, except that there is no group opposite, no representatives (or representations) of the tangata whenua to greet them, no utu. Instead, the group turns to face the audience through a proscenium arch that has been carved and decorated to reflect the façade of a wharenui. The performance in this way shifts from ritual to theatre, from acts that might be seen to be efficacious to actions that are, like Shakespearean plays, presented for applause.

The content of the Kapa Haka performance may hew closely to traditional Māori performing arts practices. It may recall waiata and haka of earlier generations while also taking inspiration, moves and music from contemporary popular culture in a way that might be recognised, in Balme's terms, as 'syncretic' or 'hybridic'. It may indeed be valorised because, after all, Māori people are the ones doing the appropriating. But for me, the real power of Kapa Haka - what I see as its confrontation with the history of colonisation - occurs at the end of each group's performance when the audience stands to haka mihi. That is, as each group completes its set and turns to exit the stage, members of the audience - generally whānau and friends - will stand and perform their response. There is no explicit protocol for this act; in fact, there are frequent requests from the judges via the emcees to refrain because it holds up the performers' exit, disrupts the entrance of the next kapa onto the stage and slows down the schedule, making long days even longer.

What happens when the audience acts back, though, is profoundly meaningful. It reclaims the haka as something alive on the ground rather than frozen in history and caught in the frame inherited from the European colonisers. The haka, thus performed, in effect breaks the stage. It becomes an act of resistance and defiance, of empowerment and selfdetermination. Kapa Haka takes us all the way, it seems, from ritual through theatre to the social. 
[Te Rita]

Kapa Haka is well entrenched in the real world now. We see troupes travelling the world to represent Aotearoa/New Zealand at various trade shows, exhibitions, cultural festivals and so on. Although not widely reported on in New Zealand, this has been happening for a number of decades. The most recent Edinburgh Tattoo was held in Britain with the attendance of Kapa Haka group members from the winning groups at the last Te Matatini, and it was also staged here in New Zealand. Not only do you have a mixture of whakapapa (genealogy) reo (language) and tikanga (cultural practice) with the combining of different Kapa Haka groups into one, but you also have the further mixture of Kapa Haka with Scottish bagpipe groups and other indigenous cultural groups from around the world. What is happening on such stages? And then you have groups like Atamira who've made careers from bringing Kapa Haka into the dance theatre. What about Hawaiiki Tū and its dance fusion? Kapa Haka is constantly being re-shaped to fit into other performance styles, and I believe that is also where its power lies, that is, it is flexible, it allows for change and development so that it does not remain stagnant but moves with the times.

\section{Footprints/Tapuwae}

[Sharon]

We've seen two versions of Footprints/Tapuwae: the first in 2001 and a revival in 2015.20 It was presented as a 'bicultural opera': one half a very condensed adaptation of Richard Wagner's Ring cycle performed by Free Theatre actors (Pākehā); the other half using elements of Kapa Haka and other Māori performing arts to tell a mythical story devised and directed by Taiporoutu Huata, and performed by Te Pao a Tahu and Te Ahikōmau a Hamo Te Rangi. In 2001, the theatre was stripped

20 Directed by Peter Falkenberg and Taiporoutu Huata for the Free Theatre. See http://www.freetheatre.org.nz/te-puna-toi-2015-footprintstapuwae.html.

Te Kaharoa, Special Edition, Ka Haka - Empowering Performance: Māori and Indigenous Performance Studies Symposium, vol. 9, 2016, 
back with the seats removed from the risers and the spectators free to follow the action - or at least find a safe corner - as performers moved through and over us. There was an enormous ramp curved through the space, with a pit below and musicians above. Even now, I remember the way we had to keep moving, together and apart, sometimes in order to see better and at other times in order to avoid being knocked by the actors or each other. The performance began with the Pākehā physically located above the Māori, and closed with the rise of the Māori to take their place at the top of the theatrical space as the Wagnerian scale was superseded by the Māori. In this, the idea was to propose a reawakening of Māori sovereignty and to question whether Wagner's nationalism might be reflected therein. The 2015 revival retained much of the original concept, but we were seated rather than standing.

[Te Rita]

In the 2001 performance, the audience could perch with reasonable comfort on the bare risers but was also able to get up and move around the stage and the props thereon. This was a novel experience for me, so I fully engaged with it, walking amongst the performers, looking up at the ramps and peering into the mine shaft as the singing took place. In the 2015 performance, the seating was difficult to sit on but there was no invitation, let alone space, to move around. Tai Huata, the coproducer and director worked with two different Kapa Haka groups to bring about the Māori part to the performance. Corban Te Aika was given the task of pulling together the group for the 2015 show. It may intrigue some who wonder how they were able to meet Wagner on his own turf. However, for those of us who are (or were) Kapa Haka exponents and composers of Kapa Haka performances it is not so strange. As Wagner comes from an earlier time and drew on historical stories, myths or otherwise, so too do composers of Kapa Haka performances bring forth the 'old' to be represented as 'new' - for example the

Te Kaharoa, Special Edition, Ka Haka - Empowering Performance: Māori and Indigenous Performance Studies Symposium, vol. 9, 2016, 
use of Māori myths and legends as composition kaupapa and the re-singing of ancient waiata and haka.

[Sharon]

Both versions of Footprints/Tapuwae were challenging for audiences, albeit in somewhat different ways, and both refused much in the way of explanation or accommodation. If you knew something of Wagner's opera, even if you couldn't catch the meanings of the words as they were sung, you could perhaps keep up with that part of the action. The same was true if you were fluent in te reo and familiar with the story being told in waiata and haka. Only Te Rita and a very few others would have been equally comfortable with both sides of the performance.

The audience's relative mobility in 2001 meant that we had to take responsibility for the act of seeing itself, to make conscious choices about where we stood relative to the performers and what they were performing. In 2015, we were seated, but because the stage was as convoluted and the action as mobile as in 2001, much of the performance was out of visual range. This was not the same as being stuck in the cheap seats, in the balcony or behind a pillar, denied a comfortable spot in the centre of row five or six (what would have been the 'king's seat' in baroque theatre). That is, there was no seat from which to see the performance whole. Our positions being fixed, we often found ourselves straining to see what was happening. Our perspective of relations between Māori and Pākehā could be seen, in this way, to be determined by our position in the theatrical encounter just as it is in the social.

Of course, not everyone watching Footprints/Tapuwae in 2015 shares my thinking about the implications of the seating. For example, Christchurch Press critic Charlie Gates begins his review by observing: 'It is a simple test that if you notice the discomfort of your seating at the theatre, the show is doing something wrong'. He then goes on to complain that it 'lacked 
the verve required to distract me from my small wooden seat'. ${ }^{21}$ Gates seems confidently unaware that displacing audiences, moving them or otherwise thwarting their desire to see is, of course, a longstanding, familiar strategy of European avantgarde theatre, in particular for political purposes. He also praises the production's 'meld' of European and Māori myths and performance traditions - its apparent syncretism. I would like to think he is mistaken. Footprints/Tapuwae could indeed be seen to have utilised the performance forms of both European and indigenous cultures in a creative recombination of their respective elements, without slavish adherence to one tradition or the other' (Balme 3). But there was no lasting point of harmonic convergence, and in its refusal to accommodate the spectator, the theatrical frame remained resistant to reconciliation.

[Te Rita]

Was there a limit to the 'taking of stage' from the Maori perspective? What happened when they came out of their little space and 'converged'? They seemed boxed in, and then tentative. It didn't feel like they were claiming it as 'their space', not like in a whakaeke. They went there because that was the prescription for the performance, and they went back as if that was their more natural home. Somehow in locking the audience into place, so too were the performers. It is possible, too, that times have changed. Fifteen years ago, we were perhaps more acutely aware of the battles being fought outside the theatre Treaty negotiations, debates about the place of te reo in everyday New Zealand life.

21 Charlie Gates, 'Review: Footprints/Tapuwae', The Press (5 June 2015). Accessed 14 August 2016. http://www.stuff.co.nz/the-press/christchurchlife/art-and-stage/69155727/ review-footprintstapuwae.

Te Kaharoa, Special Edition, Ka Haka - Empowering Performance: Māori and Indigenous Performance Studies Symposium, vol. 9, 2016, 
[Sharon]

In retrospect, the Māori side of the performance seems to have been more independent of the European in 2001 - perhaps as an unintended effect of the audience being seated, no longer free to follow the performers at will, in 2015. It is possible that this simple act - putting spectators into chairs - acts as a counterweight to radicalisation. Its conformation reminds us that we're in a theatre, after all, renews our more conventional expectations and risks our responses devolving, like the Press's reviewer's, into complaints about being made physically uncomfortable instead of feeling socially challenged. It also, potentially, reinforces existing expectations in the performers. Instead of charting their own paths throughout the space, as they did in 2001, the kapa created little proscenium-like relationships with each row of spectators in turn. In so doing they seemed less to be 'doing' Kapa Haka and more to be 'acting' than they had in 2001.

\section{The Theatrical is the Social}

[Sharon]

Can we somehow perceive a social shift reflected in the changes to Footprints/Tapuwae - in the different theatricalities and especially in the Māori side of the performance? I know that sometimes a chair is just a chair, and that Corban Te Aika's contribution, as leader of 2015's kapa, would have been significant in any case. But how might the changes inside the theatre, from 2001 to 2015 , be seen to have reflected what has happened over the past fifteen years outside? You have said that the stance taken by the Māori performers in 2001 seemed less accommodating, more radical than in 2015. Is this perhaps because Māori have made such political progress - the establishment of the Māori Party, for example, and the settlement of many more Treaty claims - so that we are bringing a lessened sense of social conflict to bear on the way we see the two groups, Māori and European, interacting theatrically? That

Te Kaharoa, Special Edition, Ka Haka - Empowering Performance: Māori and Indigenous Performance Studies Symposium, vol. 9, 2016, 
is, could some of the shift be generational and also geographical - the differences between Tai, who is from the North Island and grew up in more revolutionary times, and Corban, who is from the South and came of age as Ngāi Tahu was in the process of settling its claim?

What we see at Te Matatini has also changed over the past decade or so, especially with the way it is now produced for simultaneous broadcast, and also with the increased fluency amongst the performers. On the surface, at least, it seems less revolutionary, more part of the establishment. The audience doesn't have to stay in the arena in order to keep up with what's happening on stage; there are big screens outside, and Māori TV quickly provides video on the internet as well. That the vast majority choose to sit together still - most of them clustered closely on the grass even during massive downpours in Christchurch last year - is a testament, I think, to the power of the live performance to pull its audience into communality.

The flow of kapa onto the stage, one after the other, continues to be punctuated by the audience's own performances. It signals an ongoing rebellion against theatrical convention - the expectation that we will applaud, the attempt to stop groups from performing haka. In the end, it is, I believe, the audience's performance that reflects a refusal to be repressed and releases a revolutionary spirit that can be felt beyond the temporal and spatial limits of the theatrical event.

Dr. Te Rita Bernadette Papesch is of Waikato-Maniapoto, Ngāti Porou, Ngāti Whakaue and Czech descent. She was born and raised in Pirongia, in a family of ten siblings, by her parents and maternal grandfather. Her family encouraged her to pursue education and a musical career which began with studying classical piano and singing. She gave birth to seven children who became her focus in life. This meant a change in direction to studying Māori music under the guidance of her family, Canon Wi Te Tau Huata, Dr. Hirini Melbourne and Dr. Timoti 
Kāretu, plus many others. From 1970 onwards Kapa Haka became her passion and she now sits as the matriarch, sometimes composer and tutor, to her children and grandchildren's Kapa Haka group, Te Haona Kaha. Most of her working life has been in the field of education in the secondary and tertiary sectors. Her PhD was centred on the role of Kapa Haka in creating a modern Māori identity, and she currently lectures in the Master of Applied Indigenous Knowledge degree at Te Wānanga o Aotearoa at Mangakōtukutuku Campus in Hamilton.

Sharon Mazer earned her $\mathrm{PhD}$ at Columbia University. She is Associate Professor of Theatre and Performance Studies at Auckland University of Technology. Perhaps best known for her work on popular performance, including her book Professional Wrestling: Sport and Spectacle (Mississippi 1998), her current research focuses on diverse aspects of theatre and performance in Aotearoa New Zealand. Recent publications include articles and reviews in The Journal of Dramatic Theory \& Criticism, Performance Research, Antipodes, Theatre Journal, Theatre Survey, Australasian Drama Studies and Cultural Sociology. Forthcoming: The Intricate Art of Actually Caring . . . and other New Zealand Plays (Seagull Books 2016), the first critically framed anthology to bring together plays by Māori, Samoan and Pākehā writers; and Mātiro: Look Inside, the life and times of gay Māori performance artist, Mika. She is on the editorial boards of Performance Paradigm and Theatre Annual. 